\title{
Življenje v spreminjajoči se kitajski urbani pokrajini: študija mesta Dalian
}

Dalian je drugo najpomembnejše mesto na jugu province Liaoning na severovzhodu Kitajske. Nekoč je tam stalo naselje Qingniwa, ki so ga med letoma 1858 in 1950 drug za drugim zasedli Britanci, Japonci in Rusi. Vsak osvajalec je v mestu uvedel svoj arhitekturni slog. Rusi so mesto med drugo svetovno vojno odvzeli Japoncem, leta 1950 pa so ga končno vrnili Kitajski. Po letu 1950 je bila večina stavb in območij iz časa ruskega imperija porušena zaradi prenove, ki je potekala v mestu. Največje spremembe so se zgodile po letu 1984 , ko so mesto razglasili za posebno gospodarsko območje, zlasti pa v 90. letih 20. stoletja, ko je postal župan Bo Xilai, ki je v mestu uredil parke, avtoceste in krožišča. Tradicionalno grajeno okolje je skoraj izginilo; danes je to sodobno mesto, v katerem se gradijo obsežna stanovanjska naselja. V njem prevladujejo stano- vanjske stolpnice, v katerih živi 5,72 milijona prebivalcev. Leta 2011 je bila med 400 prebivalci opravljena anketa, v kateri so morali ti izraziti svoje mnenje o življenju v Dalianu in na njegovem ureditvenem območju ter oceniti svoje življenjske pogoje in stopnjo zadovoljstva s stanovanji. Rezultati ankete so jasno razkrili negotovost večine anketirancev glede spremenljivk, povezanih $s$ kakovostjo stanovanj ter $\mathrm{z}$ naravo, s kakovostjo in $\mathrm{z}$ dostopnostjo razpoložljivih storitev. Kljub temu je največ anketirancev navedlo, da imajo javni promet, odprte prostore, parke in rekreativne površine na voljo blizu doma.

Ključne besede: stanovanja, storitve, kakovost življenja, Dalian, Kitajska 


\section{Uvod}

»Skrb zaradi kakovosti sodobnega življenja je značilna za današnjo družbo. Družbena opazovanja so prepojena z omembami kakovosti sodobnega življenja « (Pacione, 2003: 19). Ta raziskava preučuje življenje, življenjske pogoje in stanovanja $\mathrm{v}$ hitro spreminjajoči se kitajski urbani pokrajini, temelji pa na študiji nenehno razvijajočega se mesta Dalian, ki je drugo najpomembnejše urbano območje $\mathrm{v}$ provinci Liaoning na severovzhodu Kitajske. Že na začetku je treba poudariti, da doslej še nihče ni zares raziskal kakovosti življenja v tem mestu, čeprav so bile nekatere spremenljivke, ki so jih mnogi raziskovalci uporabljali v študijah kakovosti življenja (na primer Pacione, 1990; Dunn, 2002; Smith idr., 2003; Diaz-Serrano, 2009; Baiden idr., 2011), uporabljene za ocenjevanje življenja in življenjskih razmer v mestu. Da bi lahko izvedli to študijo, je bilo treba najprej natančno preučiti teorijo kakovosti življenja in zadovoljstva s stanovanji.

Pri kakovosti življenja moramo upoštevati, kako posameznik dojema svoj položaj v kulturnem okolju in prevladujočem družbenem sistemu vrednot prebivalstva na območju, na katerem prebiva. Prav tako moramo upoštevati njegove norme, cilje, upe in strahove (Pacione, 2003; Zhou idr., 2011). Odnos med ljudmi in njihovim okoljem je pravzaprav osrednje vprašanje družbene geografije. $V$ urbanem kontekstu lahko to razumemo kot zaskrbljenost meščnov zaradi urbanega okolja, kot ga ti osebno pozitivno ali negativno dojemajo (Pacione, 2003). Razlage koncepta kakovosti življenja pa se med seboj močno razlikujejo, saj se koncept uporablja v različne namene. $\mathrm{Na}$ splošno se nanaša na razmere $\mathrm{v}$ okolju, $\mathrm{v}$ katerem ljudje živijo (naravno okolje in stanovanja), in na značilnosti prebivalcev (Pacione, 2003).

Burç Ülengin idr. (2001) navajajo, da je od leta 1930 kakovost življenja preučevalo mnogo znanstvenikov z različnih področij, saj so jo razumeli kot orodje za učinkovito razporeditev omejenih virov. Rezultate teh raziskav so uporabili za razporejanje omejenih virov $\mathrm{v}$ skladu s potrebami in prednostmi prebivalcev. Zato lahko kakovost življenja razdelimo na posamezna področja, kot so splošna kakovost življenja, telesno zdravje, psihološko zdravje, družbeni odnosi in okolje (Wang idr., 2010).

Raziskave kakovosti življenja se osredotočajo na povezavo med posamezniki in njihovim vsakdanjim okoljem, vendar tudi na možnost izboljšanja tega »vsakdanjega « življenja (Pacione, 2003; Higgins in Campanera, 2011). Kot navajajo Wim Naudé idr. (2009), so za zadnje poskuse merjenja kakovosti življenja oblikovali sezname pokazateljev, ki zajemajo širok nabor spremenljivk. Vsi pokazatelji pa imajo svoje omejitve, predvsem pa ne morejo zajeti večrazsežne narave kakovosti življenja in okoljskih vidikov tega pojava. Dodatne probleme, ki se pojavljajo pri raziskavah kakovosti življenja in njihovih protislovnih rezultatih, lahko pripišemo razlikam pri izbiri spremenljivk in njihovem uteževanju, uporabljenim pristopom in metodologiji ter, nazadnje, tudi izbranim anketirancem in homogenosti geografskega raziskovalnega območja (Ülengin idr., 2001). Težavna je tudi človeška subjektivnost. Kot navaja Margaret Westaway (2006), nekateri posamezniki kakovost svojega življenja ocenjujejo kot zelo dobro, čeprav živijo v izredno težkih razmerah in obratno. Kljub temu so raziskovalci, kot so Zahava Gabriel in Ann Bowling (2004), Bärbel Tress in Gunther Tress (2001) ter Charles Perrings (1998), ugotovili, da na splošno obstaja pozitivna povezava med visoko kakovostjo življenja in zadovoljivo fizično lokacijo oziroma okoljem.

V zvezi z najboljšim načinom ugotavljanja posameznikovega subjektivnega dobrega počutja ali zadovoljstva Luis Diaz-Serrano (2009) navaja, da lahko na to vplivajo različni dejavniki, kot so delovni pogoji, finančni položaj, stanovanje, zdravje in okolje. Stopnja zadovoljstva pri vsakem dejavniku ni odvisna samo od posameznikovih dejanskih okoliščin, ampak tudi od osebnih ambicij in želja anketirancev v zvezi s posameznim dejavnikom (Easterlin, 2006). Kljub temu znanstveniki priznavajo, da je zadovoljstvo $s$ stanovanjem med najpomembneǰ̌imi dejavniki dobre splošne kakovosti življenja posameznikov (Dunn, 2002; Smith idr., 2003; Diaz-Serrano, 2009; Baiden idr., 2011). Valerie Møller (2001) je celo trdila, da je stanovanje najpomembnejši napovedovalec življenjskega zadovoljstva. Kljub temu je zadovoljstvo s stanovanjem eno najbolj izmuzljivih meril, zaznana kakovost življenja v soseski pa eno najmanj otipljivih meril za ocenjevanje (Pacione, 2003).

Stanovanjske potrebe posameznikov zadovoljuje več stanovanjskih, sosedskih in osebnih značilnosti, ki hkrati vplivajo na te potrebe (Galster in Hesser, 1981). Gabriel in Bowling (2004) ter Anneli Kährik idr. (2012) navajajo, da posamezniki, ki živijo v soseski, ki jim daje občutek zadovoljstva in varnosti, jim omogoča dostop do komunalnih in drugih storitev in delovnega mesta ter je hkrati blizu njihovih prijateljev in drugih družinskih članov, menijo, da ta urbana pokrajina izboljšuje njihovo kakovost življenja, zlasti v poznejših letih. Poleg tega pozitivna navezanost na kraj pozitivno vpliva na spoznavne in vedenjske vezi, ki jih ljudje sčasoma razvijejo s svojim družbenim in fizičnim okoljem (Bonaiuto idr. 2003). To stanovanjsko okolje oziroma kakovost pokrajine lahko posledično močno vpliva na kakovost življenja in zadovoljstvo s stanovanjem med lokalnimi prebivalci (Temelová in Dvořákoná, 2012).

Urbana območja oblikujejo del pokrajine, v kateri živimo. Z upoštevanjem človeškega dojemanja teh pokrajin lahko razumemo povezavo med ljudmi in njihovim okoljem. Človeške dejavnosti in dejanja vplivajo na pokrajino, način, na katerega se ta pokrajina kaže navzven, pa vpliva na ljudi (Tress in Tress, 
2001; glej tudi Moolla idr., 2011). Veliko raziskovalcev je že preučevalo povezavo med sestavinami pokrajine in človeškim dojemanjem. Kot navajajo Sang-Woo Lee idr. (2008), so bile te raziskave izvajane $\mathrm{z}$ uporabo posebnih metod. Posledične klasifikacije so bile jasno razdeljene na pozitivne in negativne, obenem pa so izražale omenjeno povezavo.

V preteklosti so raziskave vedno kazale, da imajo ljudje raje naravno kot grajeno okolje in zato bolj cenijo parke, odprte površine in drevesa $\mathrm{v}$ urbani pokrajini. Taki pogoji in dojemanje vodijo $\mathrm{k}$ višji stopnji zadovoljstva s sosesko (Lee idr., 2008). Andrew McCulloch (2012) trdi, da ljudje izbirajo območja, na katerih bi rajši živeli, glede na to, kaj dojemajo kot zaželeno okolje. Trendi med britanskim prebivalstvom kažejo, da ljudje urbana območja dojemajo kot neprivlačno okolje, kar je $\mathrm{v}$ nasprotju $\mathrm{z}$ dojemanjem mestnih prebivalcev mnogih drugih evropskih dežel. Ugotovitve britanskih raziskav so pokazale, da ima visoka gostota stanovanj negativen vpliv na zadovoljstvo $s$ stanovanji in da se razmeroma bogate družine $\mathrm{z}$ otroki iz velikih mest raje preselijo na območja z manj stanovanji in prebivalci, kot so tista na mestnem obrobju, v manjša mesta in na obmorska območja, kamor se navadno preseljujejo upokojenci.

Ta študija je geografsko omejena. Ker se osredotoča na to, kako anketiranci dojemajo življenje in življenjsko okolje v spreminjajočem se urbanem okolju Daliana, natančnejša razprava pokazateljev kakovosti življenja presega temo tega članka. Cilj članka je določiti:

- družbeno-ekonomske značilnosti prebivalcev Daliana;

- značilnosti stanovanj in stopnje zadovoljstva s stanovanji med anketiranci;

- mnenja anketirancev o življenjskih razmerah v Dalianu na podlagi tega, kako dojemajo svojo okolico in kakšen dostop imajo do posameznih storitev.

Članek je razdeljen na pet delov. Prvi del vsebuje kratek zgodovinski pregled urbanističnega razvoja mesta Dalian. V drugem delu so predstavljeni uporabljeni podatki in metodologija. V tretjem delu je preučeno družbeno-ekonomsko ozadje anketirancev, $\mathrm{v}$ četrtem in petem poglavju pa so obravnavana mnenja anketirancev o lastnostih stanovanj in storitev ter značilnostih njihovih okolij oziroma okolice.

\section{Kratek zgodovinski pregled razvoja sodobnega Daliana}

Dalian je velemesto in pristanišče ter hkrati drugo največje mesto v provinci Liaoning na severovzhodu Kitajkke. Začetki pristanišča, ki so ga uporabljale tuje velesile, segajo v osemdeseta leta 19. stoletja, ko je dinastija Čing v majhnem mestu Qingniwa zgradila nakladalni most, na severni obali, kjer je danes osrednji del mesta, pa je zgradila rudarska naselja in utrdbe.
Mesto so leta 1858 zasedli Britanci, ki so tam ustanovili pomorsko bazo Port Arthur (Mu idr., 2012; Travel China Guide, 2012).V osemdesetih letih 19. stoletja je bilo območje vrnjeno Kitajski, leta 1895 pa so ga med prvo kitajkko-japonsko vojno zasedli Japonci. Po neuspelem japonskem poskusu je ruskemu imperiju leta 1898 uspelo od dinastije Čing dobiti v najem polotok, na katerem so ustanovili mesto Dalny, ki je bilo povezano $s$ transibirsko železnico in je postalo najpomembnejše rusko pristanišče v Aziji. Dalny in sosednji Port Arthur so Rusi pred letom 1904 dodatno razvijali in močno utrdili, vendar so ga morali med rusko-japonsko vojno leta 1905 predati Japonski (Mu idr., 2012; China Tour Online, 2012).

Po rusko-japonski vojni je Japonska na južni polovici današnjega Daliana oblikovala tako imenovano najeto območje Kwantung (ang. Kwantung Leased Territory). Leta 1932 je bila ustanovljena država Mandžukuo, ki ji je Kitajska poverila oblast nad najetim območjem, Japonska pa je ostala najemodajalka. Leta 1937 so Japonci posodobili območje današnjega Daliana in ga razdelili na dve mesti: Dairen (Dalian) na severu in Ryojun (Port Arthur ali Lüshun) na jugu. Po drugi svetovni vojni in brezpogojni japonski predaji avgusta 1945 je Dairen pripadel Sovjetski zvezi, ki je mesto osvobodila in mu do leta 1950 tudi vladala. V tem obdobju sta Sovjetska zveza in Kitajska mesto skupaj razvijali in se osredotočili na izgradnjo industrijske infrastrukture in pristaniških objektov. Mesto je ostalo svobodno pristanišče v najemu sovjetske vlade (China Tour Online, 2012).

Leta 1950 je Sovjetska zveza mesto vrnila kitajski komunistični vladi, 1. decembra 1950 pa se je to združilo z Lüshunom (Port Arthurjem). Leta 1955 so ga sovjetske čete zapustile. Potem se je spremenilo v veliko ladjedelniško središče, ki se je leta 1981 preimenovalo v Dalian. Leta 1984 ga je kitajska vlada razglasila za posebno gospodarsko območje, ki naj bi pritegnilo tuje naložbe in podjetja. V tistem času je bil Dalian največje kitajsko izvozno pristanišče. V devetdesetih letih 20. stoletja je napre-

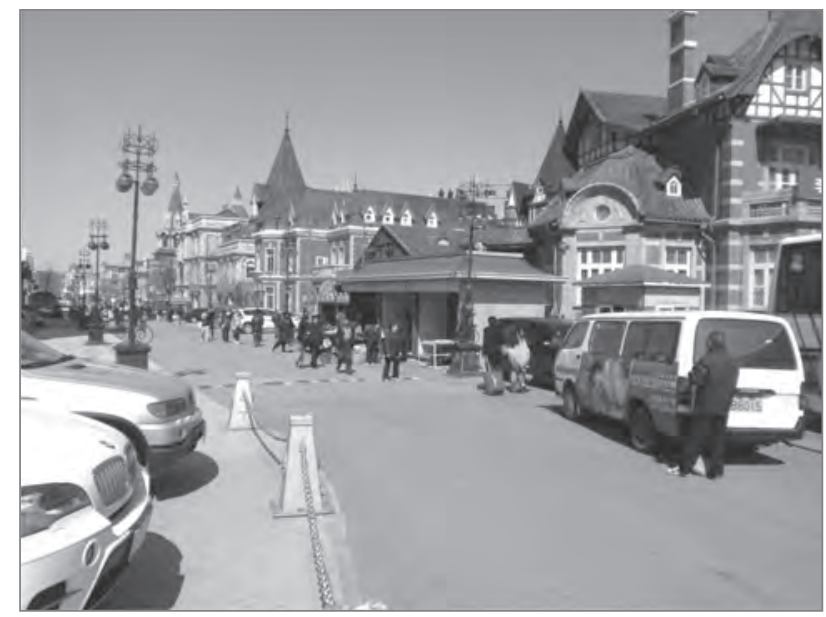

Slika 1: Ruska ulica v središču Daliana (foto: Nico Kotze) 
dovalo zaradi ukrepov župana Boja Xilaija, sicer tudi provincialnega komunističnega funkcionarja. Uredil je velike parke, avtoceste in številna krožišča (Travel China Guide, 2012). Leta 2006 je imelo mesto približno 5,72 milijona prebivalcev in bilo trinajsto največje mesto na Kitajskem (Geng idr., 2009). Čeprav je mesto izgubilo večino svoje tradicionalne arhitekture, je Xilai ohranil nekaj japonske in ruske arhitekturne dediščine ob trgu Zhongshan (glej sliko 1).

Današnje mesto je regionalno finančno središče z obsežnim industrijskim sistemom, ima pomembno vlogo v mednarodnem prevozu blaga ter je najpomembnejše kopensko in pomorsko prometno središče v severovzhodni Aziji (Geng idr., 2009). $\mathrm{V}$ mestu so bili izvedeni kratkoročni in dolgoročni razvojni ukrepi, kot so selitve tovarn, obnova opreme, uporaba tuje okoljske tehnologije in tržne spodbude za doseganje skladnosti s politiko (Shin, 2004). Oblikovane so bile tudi strategije za zmanjševanje onesnaženosti.

Danes je Dalian sodobno mesto z visokim deležem stanovanjskih stolpnic, zaradi česar je skoraj popolnoma izgubilo svoje tradicionalno grajeno okolje. Razvoj Daliana pa je sprožil druga vprašanja, povezana $z$ ogroženostjo razpoložljivih vodnih virov, $s$ čezmerno rabo podtalnice in slabšanjem kakovosti vode (Geng idr., 2009). Zaradi teh sprememb v grajenem in naravnem okolju se oblikuje to vprašanje: Kako se prebivalci tega nenehno spreminjajočega se okolja spopadajo z vsakdanjim življenjem?

\section{Zbiranje in analiza podatkov}

Vzorec je obsegal 400 enot oziroma gospodinjstev. Dvesto vprašalnikov smo razdelili v središču Daliana in dvesto na gospodarskem območju tega. Sprva smo želeli primerjati rezultate obeh območij, vendar smo to na koncu opustili zaradi zanemarljive razlike v rezultatih. Ker pa zanesljivost ugotovitev te študije ni bila preverjena z naknadnim testom, je veljavnost ugotovitev načeloma vprašljiva. Študijo potrjujeta dejstvi, da so bila vprašanja, postavljena $v$ anketi, preprosta in da anketiranci niso imeli težav z odgovarjanjem. Če so potrebovali pomoč, jim je bil vedno kdo na voljo.

Za zbiranje podatkov o demografskih spremenljivkah (spol, starost, število gospodinjskih članov in zaposlenost) in stanovanju (lastništvo, čas bivanja $\mathrm{v}$ stanovanju, število spalnic, dvigalo ter stopnje zadovoljstva s kopalnico, kuhinjo in z vsem stanovanjem) smo uporabili strukturirani vprašalnik s soglasjem o sodelovanju v raziskavi. Spremenljivkam smo pripisali vrednosti 1 (nezadovoljni), 2 (ne vem) in 3 (zadovoljni). Nato smo se osredotočili na mnenja anketirancev o njihovih soseskah in storitvah, ki lahko prispevajo $\mathrm{k}$ boljši kakovosti življenja (bližina javnega prometa, parkov, odprtih prostorov, šol in trgovin). Tudi tukaj smo uporabili tristopenjsko ocenjevalno lestvico (1 - čisto blizu, 3 - oddaljeno). Vprašalnik je bil sestavljen $\mathrm{v}$ angleškem jeziku in na prvi pogled so bili ponujeni odgovori primerni, kar je nakazovalo dobro logično veljavnost. Nato je bil vprašalnik preveden $\mathrm{v}$ mandarinščino in zdi se, da so se nekateri pomeni v končni različici izgubili, zato smo morali nekaj vprašanj izključiti.

Jezikovna pregrada in dostop do podatkov ter $s$ tem povezano število oseb, ki bi bile pripravljene sodelovati v anketi, so bili največje ovire v raziskavi. V pilotni študiji se niso pojavile nobene težave. Ko pa smo podatke obdelali, smo ugotovili, da so se nekatere podrobnosti izgubile s prevodom, zaradi česar smo morali številna vprašanja v končni študiji izključiti. Od 400 izpolnjenih vprašalnikov smo jih 12 morali izključiti, ker podani podatki niso bili popolni. Končni vzorec je torej sestavljalo 388 enot. Drugo težavo, torej dostop do anketirancev, smo rešili tako, da smo poklicali podjetja na obeh preučevanih območjih in jih prosili za dovoljenje, da lahko anketo izvedemo med njihovimi zaposlenimi. Osemnajst podjetij nam je dovolilo, da anketo izvedemo med delavci, ki želijo v njej sodelovati. Podjetja so bila različna, od podružnice ameriškega podjetja $s$ hitro prehrano do gradbenih in računalniških podjetij. V anketi so sodelovali tudi zaposleni na nacionalni univerzi v Dalianu. Tako smo deloma zagotovili, da so v raziskavi sodelovali najrazličnejši poklici in predstavniki različnih družbeno-ekonomskih položajev.

Kot navajajo Ülengin idr. (2001), lahko nastale težave in protislovne rezultate v raziskavah kakovosti življenja pripišemo razlikam v nizih izbranih spremenljivk, utežem, pripisanim tem spremenljivkam, uporabljenim pristopom in metodologijam ter tudi homogenosti anketirancev in geografskega območja. Zato smo preučili samo opisne analize nekaterih spremenljivk, ki bi lahko vplivale na življenje in življenjske razmere v Dalianu.

\section{Družbeno-ekonomske značilnosti gospodinjstev}

$\mathrm{V}$ tem delu smo preučili družbeno-ekonomske značilnosti anketirancev, ki so sodelovali pri raziskavi. Raziskava je pokazala, da v Dalianu še vedno obstaja močan patriarhalni sistem, saj je $73 \%$ anketirancev odgovorilo, da je glava družine moški (glej preglednico 1). Ob natančnejšem pregledu posameznih vprašalnikov pa smo ugotovili, da živi v mestu tudi veliko samskih žensk. Večina anketirancev je odgovorila, da je moški, ki je glava družine, star 30 let ali manj (37,9\%)oziroma po drugem najpogostejšem odgovoru od 31 do 40 let. Mogoče je, da ti rezultati niso pravilni zaradi metode, uporabljene pri zbiranju podatkov. 
Preglednica 1: Družbeno-ekonomske značilnosti gospodinjstev

\begin{tabular}{ll}
\hline Spremenljivke & Odstotek (\%) \\
\hline Spol glave družine & 73,0 \\
\hline moški & 27,0 \\
\hline ženski & 37,9 \\
\hline Starost glave družine & 36,4 \\
\hline$\leq 30$ let & 11,8 \\
\hline $31-40$ let & 13,9 \\
\hline $41-50$ let & \\
\hline$>50$ let & 28,3 \\
\hline Število ljudi v stanovanju & 44,6 \\
\hline 1 & 22,9 \\
\hline 2 & 4,2 \\
\hline 3 & 19,5 \\
\hline$\geq 4$ & 79,4 \\
\hline Izobrazba glave družine & 1,1 \\
\hline srednja šola & 28,6 \\
\hline visoka šola & 61,4 \\
\hline ni odgovora & 7,4 \\
\hline Zaposlitveni status glave družine & 2,6 \\
\hline stalno zaposlen & 4,7 \\
\hline brezposeln & \\
\hline upokojen & \\
\hline Število ljudi v gospodinjstvu, ki služijo denar & \\
\hline 1 & \\
\hline 3 ali več & \\
\hline ni odgovora & \\
\hline
\end{tabular}

Učinek politike enega otroka, ki jo je uvedla kitajska vlada, se jasno kaže v številu članov posameznih gospodinjstev. Skoraj $95 \%$ anketirancev namreč živi v največ tričlanskih gospodinjstvih. Nekaj več kot $30 \%$ pa jih je navedlo, da živijo sami (glej preglednico 1). Največji odstotek anketirancev $(42,2 \%)$ si deli stanovanje $s$ še eno osebo, 22,9\% pa jih je navedlo, da v stanovanju živijo tri osebe. Na podlagi okvirnih podatkov iz vprašalnikov lahko ugotovimo, da gre pri zadnjih za poročene pare z otrokom. Manǰsina anketirancev (4,2 \%) je navedla, da živijo skupaj štiri osebe ali več teh. $V$ večini primerov živi v gospodinjstvu eden od starih staršev ali pa si skupina mladih deli stanovanje, ki je v lasti podjetja, za katero delajo.

Kot pri starosti so tudi rezultati o zaposlitvenem statusu in izobrazbi glave družine lahko nepravilni zaradi uporabljene metode zbiranja podatkov. $91 \%$ anketirancev je navedlo, da je glava družine stalno zaposlena, pri samo $4,3 \%$ je bila glava družine brezposelna, pri 4,7\% pa upokojena (glej preglednico 1). Po drugi strani pa lahko v to kategorijo spada tudi eden od starih staršev, neporočen otrok ali brezposeln zakonski partner, ki živi $\mathrm{v}$ istem stanovanju. Večina anketirancev $(61,4 \%)$ je navedla, da živijo v gospodinjstvu, v katerem sta zaposleni dve osebi, samo
28,6 \% pa jih je navedlo, da so člani gospodinjstva, v katerem je zaposlena le ena oseba. V zvezi z izobrazbo jih je skoraj $80 \%$ navedlo, da ima glava družine visokošolsko izobrazbo, 19,5 \% pa jih ima srednješolsko izobrazbo (glej preglednico 1).

\section{Mnenja o stanovanjih v Dalianu}

Od leta 1990 so v podobi Daliana najbolj poudarjene številne stanovanjske stolpnice, $\mathrm{v}$ katerih prebivalci živijo $\mathrm{v}$ od dvo- do štirisobnih stanovanjih, katerih površina se giblje od $60 \mathrm{~m}^{2}$ ali manj za dvosobno stanovanje do $140 \mathrm{~m}^{2}$ ali več za štirisobno stanovanje. Leta 2012 je povprečno $80 \mathrm{~m}^{2}$ veliko novozgrajeno trisobno stanovanje na razvojnem območju Daliana stalo med 600.000 in 800.000 RMB (med 94.000 in 125.000 USD), odvisno od vrste zgradbe, medtem ko so bile lahko cene nepremičnin v središču Daliana zaradi velikega povpraševanja celo za $33 \%$ višje.

$\mathrm{V}$ zadnjem času cene stanovanj nenehno in izrazito rastejo, zaradi česar se premožnejši prebivalci odločajo za nakup dodatne nepremičnine, ker se bojijo, da njihovi otroci, ko bodo odrasli, ne bodo mogli sami kupiti stanovanja. Nekatera od teh stanovanj so prazna, kar se dobro vidi ponoči: v razmeroma velikem številu stanovanj ni nobenega stanovalca (to so avtorji ugotovili že leta 2010, ugotovitev pa so potrdili tudi kitajki sodelavci).

Sheila Walbe Ornstein idr. (2011) so preučevali gradnjo stanovanjskih stolpnic v São Paulu in ugotovili, da se je v njih velikost štirisobnih stanovanj s $140 \mathrm{~m}^{2}$ v 50. letih 20. stoletja zmanjšala na le $85 \mathrm{~m}^{2}$ ali manj v prvem desetletju 21. stoletja, čeprav se od 80. let več pozornosti posveča skupnim prostorom, da bi tako izboljšali udobje teh stanovanjskih enot. Ni jasno, v kolikšni meri se to dogaja v Dalianu, vendar nekateri trdijo, da se je velikost novozgrajenih stanovanj povečala, saj imajo Kitajci večje zahteve, ki so povezane z njihovim življenjskim slogom in dejstvom, da je med prebivalstvom vse več bogatih. Če pogledamo tlorise stanovanjskih novogradenj v Dalianu, lahko vidimo, da se vse več pozornosti namenja načrtom, ki stanovalcem omogočajo čim lažje gibanje v stanovanjih.

Raziskave kakovosti življenja kažejo, da lastništvo stanovanj izboljša človekovo dobro počutje in zadovoljstvo (Dunn, 2002; Smith idr., 2003; Diaz-Serrano, 2009; Baiden idr., 2011; Møller, 2001). Poleg tega je bilo za Hongkong ugotovljeno, da ni nujno, da cene stanovanj narastejo $\mathrm{z}$ izboljšanjem kakovosti okolice, ki je posledica celostne prenove starih sosesk (Yau, 2011). Raziskava značilnosti stanovanj in stopenj zadovoljstva anketirancev z njimi je razkrila, da je $70 \%$ anketirancev lastnikov stanovanja, v katerem živijo (glej preglednico 2). V vzorcu se število let, ki so jih preživeli v stanovanju, povezuje s starostjo prebivalstva, pri čemer je 65,1\% anketirancev navedlo, da v 
Preglednica 2: Stanovanja anketirancev

\begin{tabular}{ll}
\hline Spremenljivke & Odstotek (\%) \\
\hline Lastništvo & 70,3 \\
\hline lastnik & 29,7 \\
\hline najemnik & 65,1 \\
\hline Čas bivanja v stanovanju & 21,7 \\
\hline$\leq 5$ let & 6,9 \\
\hline $6-10$ let & 3,2 \\
\hline $11-15$ let & 3,1 \\
\hline $16-20$ let & \\
\hline$>$ 20 let & 28,2 \\
\hline Število spalnic & 58,5 \\
\hline 1 & 13,3 \\
\hline 2 & \\
\hline 3 & 67,2 \\
\hline Dvigalo v stavbi & 32,8 \\
\hline da & 23,8 \\
\hline ne & 32,6 \\
\hline Zadovoljni s kuhinjo & 49,9 \\
\hline da & 17,5 \\
\hline ne vem & 11,6 \\
\hline ne & 66,2 \\
\hline Zadovoljni s kopalnico & 22,2 \\
\hline da & \\
\hline ne vem & \\
\hline Zadovoljni s kakovostjo stanovanja & \\
\hline ne vem & \\
\hline
\end{tabular}

stanovanju živijo pet let ali manj, samo 3,1 \% pa jih je v istem stanovanju živelo že več kot 20 let.

Večina anketirancev (58,5\%) je navedla, da živijo v trisobnem stanovanju. To lahko pomeni, da ima današnja tipična kitajska družina tri člane, kar je v skladu z vladno politiko enega otroka. Samo 13,3 \% jih je navedlo, da imajo njihova stanovanja tri spalnice (glej preglednico 2). Več kot $67 \%$ jih je odgovorilo, da ima njihov stanovanjski blok dvigala, ki omogočajo večje udobje stanovalcev. To bi morali upoštevati tudi pri gradnji številnih stanovanjskih stolpnic v mestu.

Stopnjo zadovoljstva smo ugotavljali na podlagi merila, da ima vsako stanovanje dva prostora $\mathrm{z}$ vodovodno in električno napeljavo (to je kuhinjo in kopalnico), ki bi lahko povzročala največ težav. Zadovoljstvo $s$ tema prostoroma in $\mathrm{z}$ vsem stanovanjem je bilo razmeroma nizko. Delež anketirancev, ki so na to vprašanje odgovorili $\mathrm{z} \gg$ ne vem «, je bil razmeroma visok (skoraj $50 \%$ za kuhinjo, več kot $60 \%$ za kopalnico in $66 \%$ za vse stanovanje). To je verjetno posledica dejstva, da so
Kitajci zelo vljudni in nočejo nikogar užaliti. Kljub temu jih je $17,5 \%$ navedlo, da niso zadovoljni s kuhinjo, in $23,8 \%$, da niso zadovoljni s kopalnico. Na podlagi teh deležev lahko sklepamo, da anketiranci niso zadovoljni s stanovanji, v katerih živijo.

Tako kot v São Paulu (glej Ornstein idr., 2011) tudi v Dalianu v novozgrajenih stanovanjskih kompleksih ali drugje ponujajo dodatne ugodnosti, kot so bazeni, telovadnice, igrišča in zelene površine. V Dalianu je vse to še $\mathrm{v}$ začetni fazi in samo čas bo pokazal, ali bodo te skupne površine tudi tam dnevno tako slabo obiskane, kot se je to izkazalo v São Paulu.

\section{Mnenja o življenju v Dalianu}

V tem poglavju smo preučevali mnenja anketirancev o njihovih življenjskih pogojih, in sicer tako, da smo ugotavljali, kaj menijo o svoji okolici in bližini ponujenih storitev. Kot smo že povedali, imajo ljudje v splošnem naravno okolje raje od grajenega okolja urbanih območij in zato tudi bolj cenijo parke, odprte površine in drevesa (Lee idr., 2008). Ker se Dalian nahaja na hribovitem polotoku, je bila med načrtovanjem mesta bližina narave popolnoma realna možnost. To hitro opazimo, ko se vozimo po številnih širokih večpasovnih avtocestah v središču Daliana ter na njegovem razvojnem območju in okrog njega. Prišlekom pa se morda zdi modernistično in postmodernistično grajeno okolje sodobnega Daliana nekoliko monotono.

V Dalianu in na Kitajskem na splošno so odprte površine raznolike, od površin med zgradbami in območij z nasajenimi drevesi ob cestah do nepozidanih strmih pobočij hribov. Po drugi strani so lahko parki tudi skrbno negovani vrtovi s tlakovanimi površinami za rekreativne namene, ki so lahko različnih velikosti. Zato ni nenavadno, da je več kot $75 \%$ anketirancev navedlo, da živijo v bližini odprtih površin. Malo manj kot $62 \%$ jih je navedlo, da živijo v bližini parkov (glej preglednico 3). Pri teh dveh preučevanih spremenljivkah ni nihče menil, da so odprte površine oddaljene in nedosegljive. Na podlagi teh statističnih podatkov bi lahko sklepali, da kakovost življenja prebivalcev mesta ustreza njihovim pričakovanjem.

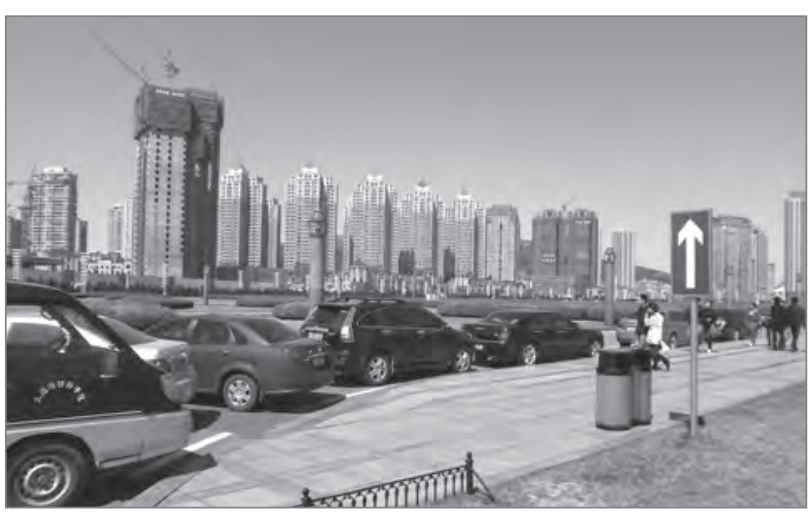

Slika 2: Trg Xinghai, največji trg v Dalianu z najdražjimi stanovanji (foto: Nico Kotze) 
Preglednica 3: Mnenja anketirancev o storitvah in okolici

\begin{tabular}{ll}
\hline Spremenljivke & Odstotek (\%) \\
\hline Oddaljenost parkov & 61,7 \\
\hline blizu & 38,3 \\
\hline ne blizu ne daleč & 0 \\
\hline daleč & 75,4 \\
\hline Oddaljenost odprtih površin & 24,6 \\
\hline blizu & 0 \\
\hline ne blizu ne daleč & 64,8 \\
\hline daleč & 29,3 \\
\hline Oddaljenost postajališč javnega prometa (avtobusi) \\
\hline blizu & 5,9 \\
\hline ne blizu ne daleč & 6,3 \\
\hline daleč & 33 \\
\hline Oddaljenost postajališč javnega prometa (vlaki) \\
\hline blizu & 60,7 \\
\hline ne blizu ne daleč & 26,8 \\
\hline daleč & 6,3 \\
\hline Oddaljenost šol & 48,4 \\
\hline blizu & 45,8 \\
\hline ne blizu ne daleč & 5,8 \\
\hline daleč & 25,8 \\
\hline Oddaljenost zdravstvenih storitev & 50,8 \\
\hline blizu & 15,5 \\
\hline ne blizu ne daleč & \\
\hline daleč & \\
\hline Oddaljenost trgovin & \\
\hline blizu & \\
\hline ne blizu ne daleč & \\
\hline daleč & \\
\hline Oddaljenost restavracij & \\
\hline blizu & \\
\hline ne blizu ne daleč & \\
\hline
\end{tabular}

Zaradi velikega števila osebnih vozil, taksijev in avtobusov na živahnih ulicah in avtocestah v središču Daliana in na njegovem razvojnem območju med delovnim časom se zdi, da promet $\mathrm{v}$ mestu ne povzroča težav. $\mathrm{V}$ primerjavi s Pekingom in Šanghajem se javni promet v Dalianu še vedno pogosto uporablja, saj je njegova raba $\mathrm{v}$ tridesetih letih upadla za samo $6 \%$ : s 74 \% leta 1975 na 68 \% leta 2005. Zaradi politike, ki spodbuja vožnjo z avtomobili, razmaha avtomobilske industrije in naraščajočega dohodka na prebivalca $v$ zadnjih desetletjih 20. stoletja pa je leta 2011 raba javnega prometa upadla na slabih 40 \% (Mu idr., 2012). Čeprav v raziskavi nismo preučevali rabe javnega prometa, je skoraj $65 \%$ anketirancev navedlo, da živijo v bližini avtobusnih postajališč in prog, le $5,9 \%$ jih je navedlo, da živijo daleč stran od teh storitev.
Dalian nima železnice ne podzemnega železniškega sistema. Območje proste trgovine (ang. Free Trade Area) in razvojno območje sta $s$ središčem mesta povezana $s$ samo eno hitro železniško progo. To je verjetno glavni razlog, da je imela večina anketirancev o teh storitvah negativno mnenje in da jih je 60,7 \% navedlo, da živijo daleč stran od železniških povezav (glej preglednico 3). Kot poročajo Rui Mu idr. (2012), je razdrobljenost mesta trenutno največji problem, povezan z javnim prometom, saj onemogoča dobre povezave.

V zvezi s šlami so nas zanimala samo mnenja anketirancev o lokaciji različnih vzgojnih in izobraževalnih ustanov (vrtcev, osnovnih in srednjih šol). Nekaj več kot $48 \%$ anketirancev je navedlo, da živijo blizu šol (glej preglednico 3). V zvezi s posameznimi vrstami šol se je izkazalo, da anketirancev lokacija in bližina vrtca in osnovne šole nista preveč skrbeli; drugače pa je bilo pri srednjih šolah. Samo nekaj več kot $46 \%$ anketirancev je odgovorilo, da živijo v bližini zdravstvenih storitev. Z anketo o zdravju, ki je potekala v kitajski provinci Zhejiang, so Biao Zhou idr. (2011) ugotovili, da so mestni prebivalci svojo kakovost življenja dojemali bolje od prebivalcev na podeželju.

Veliko stanovanjskih stolpnic v Dalianu ima v pritličju poslovne prostore $\mathrm{z}$ različnimi poslovnimi dejavnostmi, od malih trgovcev do restavracij. Zato ni običajno, da je razmeroma nizek odstotek anketirancev (33,7 \%) navedel, da živijo blizu tovrstnih storitev. Mogoče pa je, da so pri odgovarjanju imeli $\mathrm{v}$ mislih večje blagovnice - teh je v mestu manj. Visok odstotek anketirancev, ki so navedli, da živijo v bližini restavracij $(66,9 \%)$, ustreza njihovi številčnosti (glej preglednico 3).

Glede na spremenljivke, obravnavane $\mathrm{v}$ tem poglavju, prebivalci Daliana niso pretirano nezadovoljni z razpoložljivostjo odprtih površin, storitev, javnih dobrin in ugodnosti, ki razbremenjujejo vsakdanje življenje. Zato lahko sklepamo, da je kakovost življenja v Dalianu za njegove meščane sprejemljiva.

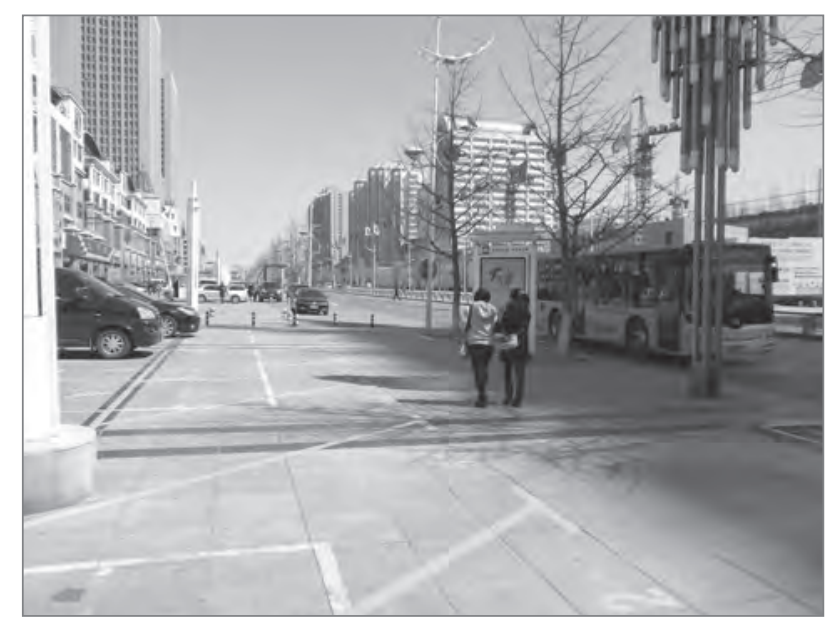

Slika 3: Razvojno območje Daliana, poslovna in stanovanjska cona (foto: Nico Kotze) 


\section{Sklep}

Čeprav se v študiji nismo osredotočali samo na kakovost življenja, smo v njej uporabili različne spremenljivke, s katerimi smo ugotavljali, kako anketiranci dojemajo življenje in življenjske pogoje v Dalianu. Z vidika družbeno-ekonomskih značilnosti so bili anketiranci mladi, imeli so visokošolsko izobrazbo in živeli v majhnih gospodinjstvih. Večina glav družine je bila stalno zaposlena in večina gospodinjstev je imela več virov dohodkov. Upoštevati pa je treba, da je na rezultate morda vplivala metoda, s katero smo zbirali podatke.

V raziskavah kakovosti življenja se parki in odprte površine dojemajo kot prvine, ki pozitivno prispevajo k boljšemu življenju na urbanih območjih. Anketiranci so v tej študiji navedli, da so jim te površine dostopne. Čeprav se je raba osebnih vozil v Dalianu po koncu 20. stoletja zaradi politik, ki so tak način prevoza spodbujale, hitro povečala, je večina anketirancev menila, da še vedno živijo blizu avtobusnih postajališč. Tudi druge storitve (zdravstvo, šole in restavracije) so se jim zdele dobro dostopne. Pri samo eni spremenljivki, to je lokaciji trgovin, so bili rezultati presenetljivi. Vse spremenljivke, ki smo jih preučevali v tej študiji, so pozitivno prispevale $\mathrm{k}$ izboljšanju življenjskih razmer in kakovosti življenja v Dalianu.

Kot pa smo že omenili, raziskovalci menijo, da sta zadovoljivo lastništvo stanovanja in zadovoljstvo s stanovanjskim okoljem pomembnejša pogoja za doseganju osebne sreče, dobrega počutja in splošne dobre kakovosti življenja. V raziskavi razmer v Dalianu smo ugotovili, da je imela večina anketirancev stanovanja v svoji lasti. V primerjavi s preostalim svetom se povprečna velikost stanovanj na Kitajskem povečuje. Ta postajajo tudi razkošnejša, saj morajo zadovoljiti zahteve kitajskega prebivalstva. Kljub temu je študija pokazala, da zadovoljstvo s stanovanji ni bilo najboljše pri kuhinjah in kopalnicah ter splošni kakovosti vsega stanovanja. Tu je bilo poudarjeno tudi dejstvo, da večina anketirancev ni vedela, kako naj pri teh spremenljivkah odgovori. To je lahko posledica slabe kakovosti dela pri stanovanjskih gradbenih projektih ali nenehnega povpraševanja po boljših stanovanjih med meščani.

\section{Juyong Zhang}

Dalian Nationalities University, Economy and Management College, Dalian, Kitajska

\section{Nico Kotze}

University of Johannesburg, Department of Geography, Environmental Management and Energy Studies, Johannesburg, Južnoafriška republika

E-pošta: nicok@uj.ac.za

\section{Minghui Yu}

Dalian Nationalities University, Economy and Management College, Dalian, Kitajska

\section{Viri in literatura}

Baiden, P., Arku, G., Luginaah, I., in Asiedu, A. B. (2011): An assessment of residents' housing satisfaction and coping in Accra, Ghana. Journal of Public Health, 19(1), str. 29-37. DOI: 10.1007/s10389-010-0348-4

Bonaiuto, M., Fornara, F., in Bonnes, M. (2003): Indexes of perceived residential environment quality and neighbourhood attachment in an urban environment: a confirmation study on the city of Rome. Landscape and Urban Planning, 65(1-2), str. 41-52. DOI: 10.1016/S01692046(02)00236-0

China Tour Online (2012): Dalian History. Dostopno na: http:// www. chinatouronline.com (sneto 23. 3. 2012).

Diaz-Serrano, L. (2009): Disentangling the housing satisfaction puzzle: Does homeownership really matter? Journal of Economic Psychology, 30(5), str. 745-755. DOI: 10.1016/j.joep.2009.06.006

Dunn, J. R. (2002): Housing and inequality in health: a study of socioeconomic dimensions of housing and self- reported health from a survey of Vancouver. Journal of Epidemical Community Health, 56(9), str. 671-681. DOI: 10.1136/jech.56.9.671

Easterlin, R. A. (2006): Life cycle happiness and its sources: Intersections of psychology, economics and demography. Journal of Economic Psychology, 27(4), str. 463-482. DOI: 10.1016/j.joep.2006.05.002

Gabriel, Z., in Bowling, A. (2004): Quality of life from the perspectives of older people. Ageing and Society, 24(5), str. 675-677. DOI: 10.1017/ S0144686X03001582

Galster, C. C., in Hesser, G. W. (1981): Residential satisfaction: Compositional and contextual correlates. Environment and Behavior, 13(6), str. 735-758. DOI: 10.1177/0013916581136006

Geng, Y., Zhu, Q., Doberstein, B., in Fujita, T. (2009): Implementing China's circular economy concept at the regional level: A review of progress in Dalian, China. Waste Management, 29(2), str. 996-1002. DOI: 10.1016/j.wasman.2008.06.036

Higgins, P., in Campanera, J. M. (2011): (Sustainable) quality of life in English city locations. Cities, 28(4), str. 290-299. DOI: 10.1016/j.cities. 2011.02.005

Kährik, A., Leetmaa, K., in Tammaru, T. (2012): Residential decision-making and satisfaction among new suburbanites in the Tallinn urban region, Estonia. Cities, 29(1), str. 49-58. DOI: 10.1016/j.cities.2011.07.005

Lee, S., Ellis, C. D., Kweon, B., in Hong, S. (2008): Relationship between landscape structure and neighbourhood satisfaction in urban areas. Landscape and Urban Planning, 85(1), str. 60-70. DOI: 10.1016/ j.landurbplan.2007.09.013

McCulloch, A. (2012): Housing density as a predictor of neighbourhood satisfaction among families with young children in urban England. Population, Space and Place, 18(1), str. 85-99. DOI: 10.1002/psp.650

Møller, V. (2001): Monitoring quality of life in cities: The Durban case. Development Southern Africa, 18(2), str. 217-238.

Moolla, R., Kotze, N., in Block, L. (2011): Zadovoljstvo s stanovanji v naselju Braamfischerville $v$ Sowetu in kakovost življenja $v$ njih: študija primera iz Južnoafriške republike [Housing satisfaction and quality of life in RDP houses in Braamfischerville, Soweto: A South African case study]. Urbani izziv, 22(1), str. 60-65 [138-143]. DOI: 10.5379/urbaniizziv-2011-22-01-005

Mu, R., De Jong, M., Yu, B., in Yang, Z. (2012): The future of the modal split in China's greenest city: Assessing options for integrating Dalian's fragmented public transport system. Policy and Society, 31(1), str. 51-71. DOI: 10.1016/j.polsoc.2012.01.002 
Naudé, W., Rossouw, S., in Krugell, W. (2009): The non-monetary quality of life in city life in South Africa. Habitat International, 33(4), str. 319326. DOI: 10.1016/j.habitatint.2008.08.004

Ornstein, S. W., Villa, S. B., in Ono, R. (2011): Residential high-rise buildings in São Paulo: Aspects related to adequacy to the occupant's needs. Journal of Housing and the Built Environment, 26(1), str. 73-84. DOI: 10.1007/s10901-010-9200-y

Pacione, M. (1990) Urban liveability. Urban Geography, 11(1), str. 1-30. DOI: $10.2747 / 0272-3638.11 .1 .1$

Pacione, M. (2003): Urban environmental quality and human wellbeing - a social geographical perspective. Landscape and Urban Planning, 65(1-2), str. 19-30. DOI: 10.1016/S0169-2046(02)00234-7

Perrings, C. (1998): Income, consumption and human development: Environmental linkages. V: United Nations Development Program (ur.): Consumption for human development. Human development report. Background paper, str. 151-212. New York, Human Development Report Office.

Shin, S. (2004): Economic globalization and the environment in China: A comparative case study of Shenyang and Dalian. Journal of Environment and Development, 13(3), str. 263-294. DOI: $10.1177 / 1070496504268352$

Smith, S. J., Easterlow, D., Munro, M., in Turner, K. T. (2003): Housing as health capital: How health trajectories and housing paths are linked. Journal of Social Issues, 59(3), str. 501-525. DOI: 10.1111/15404560.00075

Temelová, J., in Dvořákoná, N. (2012): Residential satisfaction of the elderly in city centre: The case of revitalising neighbourhoods in Prague. Cities, 29(5), str. 310-317. DOI: 10.1016/j.cities.2011.11.015

Travel China Guide (2012): Dalian Travel Guide. Dostopno na: http:// www.travelchinaguide.com (sneto 23. 3. 2012).

Tress, B., in Tress, G. (2001): Capitalising on multiplicity: A transdisciplinary systems approach to landscape research. Landscape and Urban Planning, 57(3-4), str. 142-157. DOI: 10.1016/S0169-2046(01)00200-6

Ülengin, B., Ülengin, F., in Güvenç, Ü. (2001): A multidimensional approach to urban quality of life: The case of Istanbul. European Journal of Operational Research, 130(2), str. 361-374. DOI: 10.1016/S03772217(00)00047-3

Wang, B., Li, X., Stanton, B., in Fang, X. (2010): The influence of social stigma and discriminatory experience on psychological distress and quality of life among rural-to-urban migrants in China. Social Science and Medicine, 71(1), str. 84-92. DOI: 10.1016/j.socscimed.2010.03.021

Westaway, M. S. (2006): A longitudinal investigation of satisfaction with personal and environmental quality of life in an informal South African housing settlement, Doornkop, Soweto. Habitat International, 30(1), str. 175-189. DOI: 10.1016/j.habitatint.2004.09.003

Yau, Y. (2011): Ali celovita sanacija vpliva na spremembo cen stanovanj? Študija v predelu Mongkok v Hongkongu [Does comprehensive redevelopment change the housing price gradient? A case study in Mongkok, Hong Kong]. Urbani izziv, 22(2), str. 25-33 [98-106]. DOI: 10.5379/ urbani-izziv-2011-22-02-003

Zhou, B., Chen, K., Wang, J., Wang, H., Zhang, S., in Zheng, W. (2011): Quality of life and related factors in the older rural and urban Chinese populations in Zhejiang Province. Journal of Applied Gerontology. 30(2), str. 199-225. DOI: 10.1177/0733464810361346 